\title{
Jesus in the Muslim and Christian Mystical Traditions: Ibn 'Arabi and Meister Eckhart
}

\author{
RobertJ. Dobie
}

The writings of the great mystical thinkers have become a common starting point for interreligious dialogue, no less so in Muslim-Christian dialogue. This is due to the reputation of mystical writers for pushing the doctrinal limits of their own religious traditions and of therefore 'going beyond' them. ${ }^{1}$ There is certainly something valid in this reputation, as can be exemplified by the great Andalusian Sufi Muhyaddin Ibn 'Arabi (1165-1240), who writes in his collection of erotic-mystical poetry, the Tarjiman al-Ashwaq or "The Interpreter of Desires:"

O Marvel! a garden amidst the flames

My heart has become capable of every form:

It is a pasture for gazelles and a convent for Christian monks,

And a temple for idols and the pilgrim's Ka'aba,

And the tables of the Torah and the book of the Qur'an.

I follow the religion of Love: whatever way Love's camels take,

That is my religion and my faith. ${ }^{2}$

Opened by ecstatic love, the heart of the Sufi is described as a receptacle for all that leads to God. What is more, for Ibn 'Arabi, as for many Sufis, Jesus is the model for such radical receptivity and love. Ergo, a natural place to look for convergence and commonality between Christians and Muslims would be to look at the meaning of Jesus in speculative Sufism, of which the thought of Ibn 'Arabi is probably the best example.

1 For a good discussion of ways in which this often has happened, even (or especially) in the Middle Ages, see James Heft, S. M., Reuven Firestone, \& Omid Safi, eds., Learned Ignorance: Intellectual Humility among Jews, Christians, and Muslims (Oxford: Oxford University Press, 2011), and Barbara Roggema, Marcel Poorthuis, \& Pim Valkenberg, eds., The Three Rings: Textual Studies in the Historical Trialogue of Judaism, Christianity, and Islam (Leuven: Peters, 2005), 141-62.

2 R. A. Nicholson, trans., The Tarjuman al-ashwaq: a Collection of Mystical Odes by Muhyiddin Ibn al-'Arabi (Ulan Press, 2011), 67. 
What we shall argue in this essay, however, is that the way a Muslim Suf like Ibn 'Arabi understands the figure of Jesus opens up gaps and reinforces doctrinal lines between Christianity and Islam as much as it closes and blurs them. ${ }^{3}$ The most fundamental question that Ibn 'Arabi's work proposes to MuslimChristian dialogue is this: is creaturely finitude an absolute and insurmountable obstacle to union of the human soul with God, or is creaturely finitude in some way 'redeemable' and even a necessary instrument of such union? As we shall see, Ibn 'Arabi's meditations on the meaning and significance of the 'prophethood' of Jesus expose stark differences with the Christian understanding of Jesus, which do not fit easily into any discourse of the universality of the mystical path. By way of contrast, we shall also look at the thought of a Christian mystic who was close in time as well as in spirit to Ibn 'Arabi-the Dominican friar Meister Eckhart (c.1260-1328). Examining some key themes from Eckhart's mystical writings should help us locate precisely the points of similarity and difference in Christian and Muslim approaches to the figure of Jesus.

\section{Jesus as the Essence of Prophecy in Ibn 'Arabi}

In the Sufi tradition, the prophetic figure of Jesus does not merely illustrate one 'specific and narrowly definite moral type', but rather, he illustrates the fullness

3 The same Ibn 'Arabi who wrote such beautiful and irenic poetry about how divine love can transcend religious boundaries also wrote a letter to the sultan of Konya exhorting him to apply sharia law in its full rigor to his non-Muslim subjects, restraining any public manifestations of the Christian faith lest they make "public show of their polytheism." He adds, "The worst thing that Islam and Muslims suffer in your realm is the sound of bells, the manifestation of infidelity, the affirmation of an associate of God, and the disappearance of the rules instituted by the Prince of Believers, 'Umar b. al-Khattab, regarding dhimmis: namely that neither in the city itself nor in the surrounding regions are they to build new churches, monasteries or hermitages, that they are not to prevent any Muslim from being given food and shelter in their churches for a period of up to three days, that they are not to hide spies, that they are not to conspire in secret against Muslims, that they are not to teach the Qur'an to their children, and that they are not to make public show of their polytheism" (Claude Addas, The Quest for the Red Sulphur, trans. Peter Kingsley (Cambridge: Islamic Texts Society, 1993), 235). This letter should disincline us against constructing a facile narrative of some sort of 'mystical harmony' of religions, which could so hastily be concluded from the passage cited earlier from Ibn 'Arabi's Tarjiman. Ibn 'Arabi, of course, was not just a great Sufi thinker and master but also a man of his time. As a Muslim refugee from the Christian Reconquista of Spain, his views on practical relations between Muslims and Christians would have no doubt been strongly tinged by these conditions and experiences. Cf. Abdelilah Ljami, Ibn Hazm et la polémique Islamo-Chrétienne dans l'histoire de l'Islam (Leiden-Boston: E. J. Brill, 2003). 
of the prophetic type, combining asceticism, a warm human wisdom, and miraculous powers, particularly that of raising the dead. ${ }^{4}$ Indeed, Jesus becomes something like the 'patron saint ${ }^{5}$ of the Suf tradition, and nowhere is this clearer than the important role he plays in the thought of the most philosophically sophisticated of the Sufi mystics, Ibn 'Arabi. The significance of Jesus as teacher and (Muslim) prophet is key to Ibn 'Arabi's thought, and Jesus as prophet is a central figure in his most famous work, The Bezels of Wisdom. In this work, Ibn 'Arabi regards the twenty-six prophets mentioned in the Qur'an - starting from Adam and ending with Muhammad-as 'bezels' or gem-settings, into which the various 'gems' or facets of the divine Essence are set. Each facet is, in turn, a 'word' (kalima) that 'breathes forth' and 'expresses' an aspect of divine wisdom that otherwise cannot be expressed or known in the ineffable unity of the divine Essence, but which the prophet expresses in both his life and in his message. Thus, the text has headings with titles such the 'wisdom of divinity' in the 'word of Adam' and the 'wisdom of light' in the 'word of Joseph' (who, as interpreter of dreams, casts light on the meaning of creaturely significations). In this collection of Biblical and Qur'anic prophets, Jesus holds a central place, for the 'wisdom of prophecy (nabawiyya)' resides in his 'word.' In other words, Jesus incarnates the essence of prophecy in a book that is about prophets, placing each in a setting (or bezel) for a divine word.

This preeminence of Jesus is due to his having incarnated the spirit $(r u h)$ of God in a wholly manifest way. As the Qur'an itself teaches, Jesus was born of the spirit of God blown into the Virgin Mary by the angel Gabriel. Hence, Jesus does not have a father made of flesh and blood, but is instead a direct creation of the spirit of God. It should be noted, of course, that for the Muslim Ibn 'Arabi, Jesus is still a creature and that the spirit is not God in any personal or univocal way. But Jesus does manifest in a particularly striking way how the divine spirit or 'breath' permeates, quickens, and animates the universe, for most prominent among Jesus's miracles was his ability to raise the dead: "Now the measure of life that pervades a creature is called divine, humanity being [preeminently] the locus in which the Spirit inheres. Thus humanity is called a spirit by virtue of that which inheres in it." ${ }^{\prime \prime}$ In a special way then, Jesus as prophet manifests both God's immanence in creation, as the breath or spirit

4 Tarif Khalidi, The Muslim Jesus: Sayings and Stories in Islamic Literature (Cambridge, MA: Harvard University Press, 2001), 29.

5 Khalidi, The Muslim Jesus, 34.

6 Ralph Austin, trans., The Bezels of Wisdom (Mahwah, NJ: Paulist Press, 1980), 175. References to the Arabic text are from Abulailah Affifi, ed., Fusus al-hikam (Beirut: Dar al-Kitab al-Arabi, 2002), 138-39. 
that animates it, as well as God's transcendence, insofar as Jesus is a mere creaturely manifestation.

In order to understand how Jesus functions in Ibn 'Arabi's mystical thought, we must first look at its general metaphysical/theosophical framework. Fundamental to Ibn 'Arabi's thought is his assertion of the wahdat al-wujud, or the 'unity of being (existence).' According to Ibn 'Arabi, existence in itself is one and undifferentiated. God, as one, is Existence in Itself. Creatures, insofar as they exist, exist in and through God; but insofar as they are not existence itself, and are 'this' existent but not 'that' one, they are nothing in themselves. Hence, creatures have a sort of intermediate being (they are the 'isthmus' or barzakh) between God's pure, unitary existence and nothingness.

So far, we have encountered nothing unobjectionable to orthodox Islam. But Ibn 'Arabi carries the principle of wahdat al-wujud a step further than most Muslims and even most Sufis: he argues that insofar as we conceive of God as differentiated from creation, we do not conceive of God properly as God but only as 'Lord' ( $r a b b)$ of creation, as the greatest being among beings, but still as a mere being and hence, in a sense, as a creature. The goal of Ibn 'Arabi's mystical thought, then, is to 'deconstruct' this dualism inherent in traditional monotheism and to show how God is simultaneously immanent in, but also transcendent to, his creatures. In this scheme, all creatures become 'words' of God, manifesting some truth of the divine Essence. The prophets then draw these words together into messages accessible to mankind. Therefore, as 'Abd al-Hakeem Carney puts it, the goal of the realized knower or 'gnostic' is not to theorize about the origin of creatures nor even to have an ecstatic experience that goes 'beyond' them, but rather, to listen to the creatures themselves as divine words:

Mysticism, then, does not consist in seeking out ecstatic experiences that are beyond the pale of everyday life. Rather, it is based upon a kind of listening, whereby the gnostic pays attention to the discourse that is all around him but, hitherto, he has been heedless of. It is a matter of finding God in His immanence to Creation, which means taking the Creation as nothing less than a Divine communication, a discourse between God and humans that demands to be heard. ${ }^{7}$

For a Muslim mystic like Ibn 'Arabi, the prophet does not "mark the entry of God into history" so much as overturn "human beings' comfortable belief in

7 'Abd al-Hakeem Carney, "Imamate and Love: The Discourse of the Divine in Islamic Mysticism," Journal of the American Academy of Religion, 73/3 (2005): 707. 
the God/world dichotomy." ${ }^{\text {P }}$ Thus, the prophet illuminates the immanence of God's existence - the divine wujud — by being a living and breathing manifestation of God's word. He clarifies that God's word is not other than the creatures themselves, who exhibit the plenitude of God's Essence. But at the same time, as a man limited in space and time, the prophet also points to the truth that no creature is God and that no one creature can express the divine Essence completely.

Jesus illustrates this paradox better than any other prophet in Ibn 'Arabi's Bezels. In fact, Ibn 'Arabi asserts that Jesus was indeed a word of God (although just $a$ word) and that, moreover, he was a word analogous to the word given through Muhammad to the Muslim community (umma): "Gabriel was, in fact, transmitting God's word to Mary, just as an apostle transmits His word to his community (umma). God says, He is His word deposited with Mary, and a spirit from Himself." "As the direct word of God's spirit, Jesus was also able to raise or 'animate' the dead: "Jesus came forth raising the dead because he was a divine spirit. Thus, bringing the dead to life was attributed to him both actually (mutahaqiq) and notionally (mutawahim)."10 The two terms, mutahaqiq and mutawahim, are important here because they signify the dual nature of the prophet in Ibn 'Arabi's thought. Jesus raised the dead 'actually' (mutahaqiq) insofar as he was a direct manifestation of God (al-Haqq) and his power; he raised the dead 'notionally' (mutawahim), however, insofar as he and those he raised are all creatures analogous to a dream or a 'presumption' (=wahm) in relation to God. In this way, Jesus points to the instability of any absolute distinction between God and the world, while at the same time acknowledging his own creaturely nothingness.

Furthermore, Jesus's humility is a crucial factor to this destabilization of any absolute difference between God and the world. In Ibn 'Arabi's Sufi thought, Jesus' humility draws our attention to the utter 'poverty' ( fuqura) of creatures in the face of the 'richness' (ghania') of God's being. Creatures are 'poor' in that they are 'as if nothing' or 'having nothing' in comparison to God's absolute being. Accordingly, Ibn 'Arabi emphasizes Jesus's own poverty and humility right near the beginning of his bezel on Jesus. What is at first striking here are the political implications he draws from it:

The humility of Jesus was such that his community was commanded that they should pay the poll-tax completely, humbling themselves, that if any

\footnotetext{
8 Ibid., 714 .

9 Austin, 175/Affifi, 139 .

10 Austin, 176/Affifi, 139-40.
} 
one of them were struck on one cheek, he should offer also the other, and that he should not hit back or seek retribution. This aspect [of his teaching] derives from his mother, since woman is lowly and humble, being under the man, both theoretically and physically. His powers of revival, on the other hand, derive from the blowing of Gabriel in human form, since Jesus revived the dead in human form. ${ }^{11}$

But almost immediately thereafter, Ibn 'Arabi brings the discussion of Jesus's humility and asceticism back to metaphysical issues, discussing how the humility and poverty of Jesus allow the divine spirit to work its animating power on creatures. Hence, the casual observer would see him as a 'mortal man performing divine acts:'

It used to be said of him, when he revived the dead, "It is he and yet not he (huwa la huwa)." Both the sight of the observer and the mind of the intelligent man were confused (wa taqa' al-hayra) at seeing a mortal man bring the dead to life, rationally as well as physically, which is a divine prerogative. The spectator would be utterly bewildered to see a mortal man performing divine acts. ${ }^{12}$

There are two terms or phrases here that are important in Sufi thought. The first is that Jesus manifested in a powerful way the truth that each creature is 'He and not He,' in other words, that each creature is in a way God ('He'), insofar as it derives all of its existence from God, but also that each creature is radically other than God, or 'nothing' ('not He'), inasmuch as the creature is bound and limited by both its form and matter. Thus, in his poverty and humility Jesus demonstrates that he is a creature, as he is utterly poor with respect to being; but insofar as in his creaturely nothingness he reveals divine power and raises the dead, he is a theophany - a manifestation of the divine Essence within created being.

11 Austin, 177/Affifi, 140. We perhaps find an echo here of the letter to the sultan of Konya cited earlier. At work here also may be the idea of Jesus as a model of irja' in the Sufi tradition. This is a term denoting an early Muslim movement which generally avoided becoming involved in civil wars and refrained from branding any Muslim an unbeliever because of doctrinal differences, provided faith in one God was not abandoned. Khalidi also notes that Ibn 'Arabi's representation of Jesus reflects the increasing tension between Sufis and legal scholars in his time. Jesus was conventionally inducted into this struggle on the side of the Sufis because of his perceived disapproval of narrow-minded legalism. See Khalidi, The Muslim Jesus, 35, 202. 
For Ibn 'Arabi, those who observed the miracles of Jesus were 'confused' or 'bewildered' by what they saw: a mere mortal performing divine acts. The term for 'confused' or 'bewildered,' hayra, is the second important Sufi term. Hayra refers to that 'stage' ( $\mathrm{hal}$ ) in which the dichotomy between the world and God as a distinct Lord collapses. It is therefore one of the highest stages in the Sufi quest, because it is here that the Sufi experiences God's simultaneous immanence and transcendence in himself and in all creatures. But, according to Ibn 'Arabi, the early Christians misinterpreted their bewilderment and mistakenly attributed divinity to the man Jesus, and so they speak of God's incarnation:

This matter has led certain people to speak of incarnation and to say that, in reviving the dead, he is God. Therefore, they are called unbelievers [concealers], being a form of concealment, since they conceal God, Who in reality revives the dead, in the human form of Jesus. He has said, They are concealers [unbelievers] who say that God is the Messiah, son of Mary. The real error and unbelief in the full sense of the word is not in their saying "He is God" nor "the son of Mary," but in their having turned aside from God by including [God in human form] in the matter of reviving the dead, in favor of a merely mortal form in their saying [He is] the son of Mary, albeit that he is the son of Mary without doubt. Hearing them, one might think that they attributed divinity to the form, making it the form itself, but that is not the case, having in fact asserted that the divine Identity is the subject in the human form, which was the son of Mary. Thus they distinguished between the form and the determination, but did not make the form the same as the determining principle. In the same way, Gabriel was in mortal form [at first] without blowing [into Mary]; then he blew [into her]. Thus the blowing is distinguished from the form, since, although it derives from the form, it is not of its essence. So do the various sects quarrel concerning the nature of Jesus. ${ }^{13}$

I cite Ibn 'Arabi at length here because this passage is central, I believe, to his and the entire Sufi and Muslim understanding of Jesus. The first thing to note here is that Ibn 'Arabi argues that calling Jesus the 'son of God' is neither incorrect nor blasphemy. As Carney explains:

The statement that Jesus is God is not blasphemy. It is, in fact, correct. Al-Qaysari [a medieval Muslim commentator on Ibn 'Arabi's Bezels] writes explicitly that the statement that Jesus is God is correct and true

Austin, 177-78/Affifi, 141. 
insofar as Jesus is a specific epiphanic manifestation of the Divine Being (al-haqq). And the statement that he is the son of Mary is true without any doubt. The act of disbelief, according to Ibn 'Arabi, is the union of the two statements, that is, that Jesus the son of Mary (meaning his nasut) is God. It is the confusion of the human nature of Jesus (symbolized by referring to him as the son of Mary) and the Divine that is the source of the problem, not the idea that Jesus as a theophanic being is identical to God. ${ }^{14}$

The mistake is therefore to confuse the limits or form of the manifestation of God with the divine manifestation itself. Carney then continues to explain:

The problem is not that Jesus is God; this is accepted on face value. The problem is rather that Jesus as a physical being is also a negation of God, because by bringing God out in a particular form (in the case of Jesus, a particularly high form), Jesus qua Jesus is a negation of God, that space in which the Manifest God may come into being. ${ }^{15}$

All finite essences and, a fortiori, all material or physical beings are thus seen as negations of the plenitude of God's Essence. Accordingly, Jesus manifests God and the divine Essence by his divine powers and acts made possible by his receptive humility, and yet he also negates that Essence by the finitude of his humanity and the particularity of his physicality. Ergo, Muslims properly understand Jesus as a mere man and prophet and not as the incarnate Son of God.

Moreover, as Carney points out, this tension between manifestation and negation in Jesus plays out in the reception of the divine word that Jesus manifests. This occurs because all particularity, in effect, alters and distorts the divine word, such that while the divine Essence is made manifest and revealed in the prophetic discourse, it is also distorted and even negated by the very particularity of that discourse:

14 Carney, "Imamate and Love," 716. As Mahmoud Ayoub observes in connection with this point: "Islam draws an absolute distinction between the creator and all created things. Yet ideas such as Ibn al-Arabi's wahdat al-wujud, 'unity of being', can easily accommodate notions of divine sonship" (Mahmoud Ayoub, A Muslim View of Christianity: Essays on Dialogue (New York: Orbis Books, 2007), 128).

15 Carney, "Imamate and Love," 717. 
It is not so much that the subject "reads" into the Divine discourse that which he wants to hear. It is rather the subject qua subject that causes this distortion. It is something implicit in the subject's very subjectivity, in his existence as a being that is simultaneously a sign and manifestation of the Divine discourse (for everything in the universe), and at the same time marks the entry of a fundamental negativity within the Divine being, as a not-God that assures him no other role except as servant ('abd) to the Divine being. This dual situation, these "two natures" (a union that exists in a non-hypostatic fashion) that are united inside the servant, is made clear in Ibn 'Arabi's description of the universe as Huwa/La Huwa, "Him, not Him."16

Hence, Jesus's first followers by necessity misunderstood him and attributed divinity to his human nature and to his individual particularity. In other words, the early Christians did not understand that Jesus was both 'He' and 'not He.' Nevertheless, this was understandable given that Jesus, according to the Qur'an itself, had no human father:

Thus he is [at once] the Word of God, the Spirit of God, and the slave of God, and such a [triple] manifestation in sensible form belongs to no other. Every other man is attributed to his formal father, not to the one who blows His Spirit into human form. God, when He perfected the human body, as He says, When I perfected him, blew into him of His spirit, attributing all spirit in man's being and essence to Himself. The case of Jesus is otherwise, since the perfection of his body and human form was included in the blowing of the spirit [by Gabriel into Mary], which is not so of other men. All creatures are indeed words of God, which are inexhaustible, stemming as they do from [the command] $B e$, which is the Word of God. Now, can the Word be attributed to God as He is in Himself, so that its nature may never be known, or can God descend to the form of him who says $B e$, so that the word $B e$ may be said to be the reality of the form to which He descends and in which He is manifest? Some gnostics support the former, some the latter, while others are confused and do not know what is the truth of the matter. ${ }^{17}$

In this scheme of things, any word from God both reveals God and at the same time (and to the same degree) conceals or even negates the divine word.

16 Carney, "Imamate and Love," 709.

17 Austin, 178/Affifi, 142. 
As explained above, this problem applies not just to 'prophetic words' but to all creatures, since all creatures are words of God. However, Ibn 'Arabi leaves this matter an open question, simply saying that it can only be resolved by 'taste' (dhawq) or 'direct experience.'18 What might this 'taste' that resolves the matter tell us?

As Ibn 'Arabi continues to explain in his bezel on Jesus, we must conceive of the universe and all its forms as being received, as it were, into the Divine Breath as their Primordial Substance, which is Nature herself. ${ }^{19}$ This Breath makes manifest the divine Names, which otherwise remain hidden in the divine Essence, for the divine Names materialize only in their relation to creatures (such as the 'Merciful' or the 'Exalted'). The Essence in itself, however, is beyond these Names and their 'conflicts' (because the Names often indicate attributes that to our limited view seem to be in conflict, such as the 'Avenger' and the 'Merciful'). ${ }^{20}$ Ibn 'Arabi points this out only to make a comparison between the universe (the macrocosm) and the individual soul (the microcosm):

Whoever wishes to know the divine Breath, then let him [first] know the Cosmos, for "Who knows himself, knows his Lord," Who is manifest in him. In other words, the Cosmos is manifested in the divine Breath by which God relieved the divine Names from the distress they experienced by the nonmanifestation of their effects. Thus He bestows favor on Himself by what He creates in His breath. Indeed, the first effect of the Breath is experienced only in the divine Presence, after which it continues its descent by a universal [process] of release, down to the last thing to be created. ${ }^{21}$

So in the individual human being, the divine Essence is paradoxically manifest in the non-manifest consciousness, or internal witness, that makes all aware-

18 Affifi, 141.

19 "The Reality describes Himself as the Merciful Breath, and that all that attaches to an attribute, in the case of something described, should adhere to that attribute. You know that the breath in one breathing is all that needs to be. Therefore, the Divine Breath is receptive to cosmic forms, in relation to which it is like the Primordial Substance, being very Nature Herself" (Austin, 179-80/Affifi, 143-44).

20 "Indeed it is the Breath that has brought about the mutual conflict among the divine Names, which are relationships. Consider, however, how the divine Essence, which is beyond this regime [of conflict], is characterized by [utter] Self-sufficiency, beyond all need of the Cosmos. Because of this the Cosmos has been set forth in the form of its Creator, which is nothing other than the divine Breath" (Austin, 180/Affifi, 144). 
ness possible. This internal witness is constituted by the awareness of the unity of all being or existence as such, and so it is in this internal witness that being or existence is 'found' (mawjud — 'is found' or 'exists') as such. ${ }^{22}$ In this way, Ibn 'Arabi extends his destabilization of the God/world dichotomy even further, so that it includes God and the human individual:

[So I said], Worship God. He uses the name Allah because of the variety of worshippers in their acts of worship and the different religious traditions. He does not use one of the particular names, but rather that Name which includes them all. Then he goes on to say, My Lord and your Lord, whence it is certain that His relationship with one creature, as Lord, is not the same as with another. For that reason he makes the distinction between My Lord and your Lord, referring separately to the speaker and the one spoken to. ${ }^{23}$

God is both immanent in and transcendent to the soul. Accordingly, 'Lord' $(r a b b)$ is a term that applies to God when the soul regards God as an object over and against itself, taken in its creaturely finitude and material particularity. But insofar as the soul is conscious of the unity of being, then the boundary and distinction between it and God is fluid and even illusory. No other prophet demonstrates this fluidity for Ibn 'Arabi better than Jesus:

He continued, And when You caused me to die, that is, when You raised me to Yourself, hiding them from me and me from them, You were the watcher over them, not in my material substance, but in theirs, since You were their sight, which required supervision. Man's consciousness of himself is indeed God's consciousness to the name, the Watcher, referring the consciousness to Him. He wishes thereby to distinguish between himself and his Lord, so that he may know that he is himself, a servant, that God is Himself as his Lord, considering himself as witness and God as the Watcher. Thus, in relation to himself, Jesus puts his people first, saying, concerning them a witness, while I am with them, preferring them out of courtesy. He places them last, however, when speaking of God in saying, the Watcher over them, since the Lord is deserving of precedence. ${ }^{24}$

As Peter Coates comments: "For Ibn 'Arabi consciousness of the Self, in its metaphysical depths, is nothing less than consciousness of the Unity of Being" (Peter Coates, Ibn Arabi and Modern Thought (Oxford: Anqa Publishing, 2002), 172). 
Thus, Jesus epitomizes the hadith that states that in the servant who loves God with a pure love, God becomes his 'hearing' and his 'seeing' and his 'walking.'25 God in such a 'knower' (gnostic or 'arif) 'animates' the knower's every act and is, therefore, the 'observer' or 'watcher' (shahid) that grounds every act of awareness and knowing. Furthermore, it is in awareness of this fundamental awareness that the soul comes to 'taste' God as the Watcher (shahid) within.

Ibn 'Arabi is fond of quoting his great Sufi predecessor, Junayd, who used to say about knowledge (ma'arifa) and the knower ('arif): "The water takes on the color of its cup."26 That is, the knowledge that the Sufi has of God (the water) is colored by conditions of his creaturely finitude. We cannot, however, do without the cup, since it is by means of the cup (the sacred text, the sacred tradition) that the water (divine knowledge) becomes accessible to the created intellect. We can only attain divine knowledge, therefore, by taste (dhawq), i.e., by drinking the water in the cup. But a pure, undistorted knowledge of the divine Essence as such (the water as it is devoid of color outside the cup) is impossible. Ibn 'Arabi extends this notion to understand religion itself: thus, the different religions (adyan-din, sing.) take the shape of many different cups, each holding the water of divine knowledge, even though Islam is the clearest and most capacious cup. In this analogy, every religion or din (law) is a 'cup' that 'colors' its view or notion of God (which Ibn 'Arabi calls the 'God of belief,' as opposed to God himself in his hidden Essence). Thus, the Sufi solution to Muslim-Christian dialogue (or, more narrowly, Ibn 'Arabi's solution) is to approach the two religious traditions as two cups out of which the divine Essence may be drunk and tasted, but in which knowledge of God as such eludes the soul, due to its inherent finitude and the historically limited nature of human tradition.

25 Austin, 184/Affifi, 148.

26 Ibn 'Arabi expands upon the saying of Junayd in Meccan Revelations: "Junayd was asked about knowledge (ma'arifa) and the knower ('arif). He replied 'The water takes on the color of its cup'. In other words, the container displays its effects in what it contains. Junayd said this to let you know that you will never judge your object of knowledge except by yourself, since you will never know anything but yourself. Whatever may be the color of the cup, water becomes manifest in that color. The person without knowledge judges that the water is like that, since sight gives that to him. Water discloses itself in the forms of all the cups in respect to their colors, but it does not become delimited in its essence. You only see it that way. In the same manner, the shapes of the containers in which water appears display their effects in it, but in all of them it is still water. If the container is square, the water becomes manifest as square" (Al-Futuhat al-Makkiyya, III, 161.24, translated by William Chittick in The Sufi Path of Knowledge (Albany, NY: State University of New York Press, 1989), 341). 
There is, however, a problem inherent in this solution, as attractive as it might be to the modern mind. Such a solution depends upon an understanding of Jesus, and of divine knowledge in general, that is fundamentally gnostic (in the late antique Hellenistic sense of the term). Here, materiality and created finitude are insurmountable obstacles to knowledge of the divine, and so we must conceive of the knower (or Knower, God) not only as pure spirit, but also as spirit that is purified from matter and finitude and thus totally beyond the human condition as such. Not only is this assertion something any knowledgeable Christian cannot accept, but it also leads to a tension, maybe even a contradiction, internal to Ibn 'Arabi's own speculative Sufism: it asserts a fundamental and insurmountable duality in a system whose entire goal is to surmount or at least destabilize all dualist thinking. Material individuality and the finitude of the creaturely essence can therefore be recognized and relativized in relation to the Sufi's awareness of the oneness of the divine Essence, but they can never be wholly overcome. So, while we can destabilize the God/ world and God/soul distinctions in human language, these distinctions remain insurmountable in reality.

\section{Jesus as the 'Negation of Negation' in Meister Eckhart}

To make clearer what is at stake for Muslim-Christian dialogue, it will be helpful to look at the thought of a Christian mystic close to Ibn 'Arabi not only in time, but also in the fundamental outlines of his mystical thought. Meister Eckhart is such a mystic. The way he appropriates the Christian tradition in the service of a mystical reading of scripture is analogous to Ibn 'Arabi in striking ways. ${ }^{27}$ Like Ibn 'Arabi, Eckhart attempts to disrupt and go beyond any fixed God/world and God/soul dichotomy, thus opening up an understanding of God and his Word that sees their identity in difference and immanence in transcendence. Eckhart himself even talks of a 'God beyond "God," ' meaning not the remote god of ancient Gnosticism but, on the contrary, the living God who is the ground of our very being, knowing, and willing. Indeed, in one of his vernacular sermons, Eckhart asks his hearers to pray to God that we might be free of God, where God is understood as a being distinct and separate from us who is only one being among other beings (even if the greatest or first). With this, we find a way of thinking that is very similar to Ibn 'Arabi. Eckhart also

27 For a much fuller comparative analysis of the mystical thought of these two thinkers, see my book Logos and Revelation: Ibn 'Arabi, Meister Eckhart and Mystical Hermeneutics (Washington, DC: Catholic University of America Press, 2010). 
asserts the 'nothingness' of creatures in comparison to God, claiming that creatures are utterly poor with respect to God, and derive all of their being, oneness, truth, and goodness from God. Thus, for Eckhart, Existence (esse) Itself is God, and creatures are but negations of that pure, unrestricted Existence. ${ }^{28}$

Eckhart, however, goes further. In his thinking, the negativity of the creature is not an absolute barrier between God and man. This is because we cannot logically stop at the mere negativity of the creature or at God's absolute existence, since this would reinforce the duality that he strives to break. Thus, on a higher plane, we must also conceive of God as the negation of negation (negatio negationis), which is simultaneously the purest affirmation of being or existence. Since pure existence (Existence in Itself) is God, God is also the negation of all that may limit or deny existence, which does not, however, deny the limited, individual existence of creatures as existents:

But to existence itself no existence is denied, just as to animal itself is not denied this animal, for example, "lion." Therefore, no negation, nothing negative, belongs to God, except the negation of negation which is what the One signifies when expressed negatively.... The negation of negation is the purest and fullest affirmation - "I am who am" ... Existence cannot deny that it is Existence Itself. ${ }^{29}$

What is important here is that Eckhart asserts that the negation of negation as found in God's utter unity is also a pure and full affirmation. No existence-not even limited, finite, material existence — can be denied to God, if God is indeed the fullness and perfection of Existence Itself. So, just as 'lion' cannot be denied to the category of animal itself, no limited, finite creaturely existence can be denied to God. Of course, this does not mean that God is indistinct from all creatures or that creatures and God are simply one and the same; rather, creatures are radically distinct from God precisely insofar as they are negations of pure existence, but not negations of that negation. Nevertheless, Eckhart argues that no negation as such is or can be absolute; it exists only to be negated in God's purity of being and oneness.

28 See Eckhart's prologues to his Opus Tripartitum, found in Meister Eckhart: Die Lateinische Werke, Vol. I (Stuttgart: Kohlhammer Verlag, 1936- ), 148-84 (henceforth LW); translated in Armand A. Maurer, Master Eckhart: Parisian Questions and Prologues (Toronto: Pontifical Institute of Medieval Studies, 1974), 77-105.

29 In Exod., n. 74 in LW, Vol. II, 77; translated in Bernard McGinn, Meister Eckhart: Teacher and Preacher (Mahwah, NJ: Paulist Press, 1986), 68. 
This dialectic of the 'negation of the negation' holds for the human being as well, and his or her relationship to God. Human nature does not erect an insurmountable barrier between man and God (as was posited by Ibn 'Arabi), but actually opens up the possibility of unity by the very fact that human nature, as both material and spiritual, as embodied yet open to the universality of being by virtue of its intellectual nature, is able to become a locus of the divine negation of negation. And, to the extent that the human soul is capable of freedom from the material conditions of existence by virtue of its intellectual nature, human nature is capable of being assumed by the divine nature in such a way that human nature as such is affirmed in the hypostatic unity of Christ:

Man is an accident of nature. Therefore, abandon everything that is accident in you and preserve yourself as free, undivided human nature. Since this same nature which you possess has become the Son of the eternal Father through its being assumed by the eternal Word, you become the Son of the eternal Father with Christ because you have the same nature which has become God. Therefore, be careful not in the least to hold onto yourself as you are this person or that, but preserve yourself as a free, undivided human nature. And so, if you want to be one Son, separate yourself from all nothing because nothing causes distinction. How is that? Note the following. That you are not a certain person, it is the not which differentiates you from this person. If you want to be without distinction, rid yourself of not (nihte). There is a power in the soul which is separated from nothing since it has nothing in common with any things. Nothing is in this power but God alone. He shines naked into this power. ${ }^{30}$

It is not materiality or finitude that prevents the union of the human soul with Christ - for Christ had assumed both — but rather, it is the soul's attachment to that materiality and finitude. For Eckhart, Christ points the way (through his Incarnation and his death on the cross) to this negation of negation, in which God and world, as well as God and soul, become one without becoming the same. Insofar as we love our neighbor in self-sacrifice, we dwell in our 'undivided' human nature, which is nothing other than the undivided divine nature as well, for human nature in its purity (Christ) is nothing other than the divine nature itself. ${ }^{31}$ Hence, in Eckhart's mystical thought, creaturely finitude and

$30 \quad$ Predigt 46 in LW, Vol. II, 380-82; translated in McGinn, Meister Eckhart, 304-05.

31 Dobie, Logos and Revelation, 154. 
material individuality are united to God and can be united to God insofar as our human nature is redeemed. Our knowledge of this redemption, furthermore, cannot come from the powers of reason alone, but can only be revealed in the birth, death, and resurrection of Christ. ${ }^{32}$ Nevertheless, the powers of human reason and human language are also redeemed, insofar as Christ is the incarnate Word of God. As incarnate Word, Christ not only fully manifests God's presence, but he also takes up and negates the negation of finitude and materiality through the communication of the divine Word, thus making both finitude and materiality fitting vehicles for God's full self-expression. In this way, the soul's intellectual nature is also fulfilled, because it is the nature of the intellect to be "separated from nothing since it has nothing in common with anything." Accordingly, the play of revelation and concealment that we saw with the divine words in Ibn 'Arabi is overcome.

We therefore go 'beyond' the 'God' of creation, to the extent that we see God has united himself essentially and completely to our human nature in Christ, so that what is fully human is also fully divine, and what is fully divine is not alien to anything that is fully human — materiality and finitude included.

For Eckhart, the fact of the Incarnation contains the inner truth of Christianity. The Incarnation tells us that God in the person of Christ did not think 'divinity something to be held onto' but that he 'emptied himself' by becoming a human being (Phil 2:6-8). By doing so the eternal breaks into historical time and abiding truth into the world of shifting phenomena. $^{33}$

Furthermore, the breaking of the eternal into the temporal, the uncreated into the created, and the divine into the human, are all expressed by Meister Eckhart in terms of birth - the birth of the Son into the soul. In this incarna-

32 As Mahmoud Ayoub points out, Islam has no conception of sin and redemption: see his A Muslim View of Christianity, 137. Thus, in Islam in general, and the Sufi tradition in particular, Jesus becomes only an example of piety, love, and asceticism, which is to be emulated. Christ also exemplifies a fulfilled humanity, a humanity illumined by the light of God. This reflection of the divine light in the human heart and soul is known in the language of Islamic mysticism as tajalli, the manifestation of divine beauty and majesty in and through man (Ayoub, A Muslim View of Christianity, 152). Nevertheless, according to Islam and even the thought of someone like Ibn 'Arabi, who was unafraid to stretch doctrinal points, human and divine nature always remain distinct and separate. Thus, as prophet, Jesus can do nothing to affect any unity between God and human beings-he can only be an example or point to the way, not be the way itself. 
tional language of 'birth,' God becomes the lived ground for knowledge, will, and action in the soul where this 'event' has occurred. In this event, any radical dichotomy between word and God or soul and God is abolished; however, in the very act of birth, the materiality and individuality of the believer is also affirmed. In this sense then, it is the affective fulfillment and perfection of the 'negation of negation.'

\section{Ibn 'Arabi, Meister Eckhart, and Interreligious Dialogue}

As noted above, the thought of a Christian mystic like Meister Eckhart has features strikingly similar to that of a Muslim Sufi like Ibn 'Arabi. They both attempt to draw the believer into a deeper appreciation of the 'identity in difference' and 'difference in identity' between God and the world on one hand, and God and soul, on the other. They both do this by pointing to a conceptual difference between God as he is in his Essence, utterly one in himself and with all things (immanent in his transcendence), and God as 'Lord' of creation, as a being distinct and apart from his creation. These, of course, are not two different 'gods,' but one and the same God viewed from different angles, though the first perspective for both our mystics is clearly more adequate and comprehensive than the second. Furthermore, Ibn 'Arabi and Meister Eckhart use similar strategies to effect this shift in perspective for their hearers and readers: both stretch language to the limit, engage in what appears to be blasphemy, and often read sacred texts against themselves. But, as we have pointed out above, there are limits to this convergence. The most important limit is in the notion of redemption, which is totally absent from Islam and thus from the mystical thought of Ibn 'Arabi as well. Thus, while a Christian mystic like Meister Eckhart might find much to appreciate in the writings of Ibn 'Arabithe unity and oneness of God, his immanence in transcendence, the importance of the biblical prophets - he would find it jarring that there is a lack of any notion of the Fall, the Incarnation, the atoning sacrifice of the Cross, and our redemption. For Eckhart, it is precisely this redemptive character of Christ that completes the dialectic of God's immanence in transcendence, which we found only partially complete in Ibn 'Arabi's thought.

If, however, a proper appreciation of difference is the foundation of genuine interreligious dialogue, then our two mystical thinkers have laid the groundwork for this very well indeed. 